Hydrol. Earth Syst. Sci., 14, 1581-1594, 2010

www.hydrol-earth-syst-sci.net/14/1581/2010/

doi: $10.5194 /$ hess-14-1581-2010

(C) Author(s) 2010. CC Attribution 3.0 License.

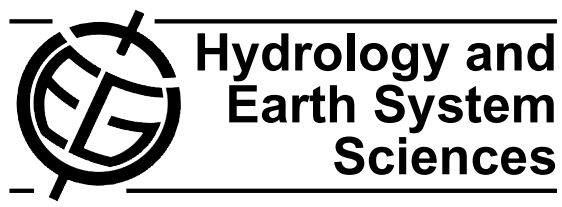

\title{
Changes in flood frequencies in Switzerland since 1500
}

\author{
P. Schmocker-Fackel ${ }^{1, *}$ and F. Naef ${ }^{2}$ \\ ${ }^{1}$ Mountain Hydrology and Torrents, Swiss Federal Research Institute WSL, Switzerland \\ ${ }^{2}$ Institute for Environmental Engineering, Swiss Federal Institute of Technology Zürich, ETHZ, Switzerland \\ *now at: Hydrology Division, Federal Office for the Environment FOEN, Bern, Switzerland
}

Received: 21 December 2009 - Published in Hydrol. Earth Syst. Sci. Discuss.: 21 January 2010

Revised: 6 July 2010 - Accepted: 12 July 2010 - Published: 17 August 2010

\begin{abstract}
In northern Switzerland, an accumulation of large flood events has occurred since the 1970s, preceded by a prolonged period with few floods (Schmocker-Fackel and Naef, 2010). How have Swiss flood frequencies changed over the past 500 years? And how does the recent increase in flood frequencies compare with other periods in this half millennium? We collected historical flood data for 14 Swiss catchments dating back to $1500 \mathrm{AC}$. All catchments experienced marked fluctuations in flood frequencies, and we were able to identify four periods of frequent flooding in northern Switzerland, lasting between 30 and 100 years (1560-1590, 1740-1790, 1820-1940 and since 1970). The current period of increased flood frequencies has not yet exceeded those observed in the past. We tested whether the flood frequency fluctuation could be explained with generalised climatic indices like solar activity or the NAO. The first three periods of low flood frequency in Switzerland correspond to periods of low solar activity. However, after 1810 no relationship between solar activity and flood frequency was found, nor could a relationship be established between reconstructed NAO indices or reconstructed Swiss temperatures. We found re-occurring spatial patterns of flood frequencies on a European scale, with the Swiss periods of frequent flooding often in phase with those in the Czech Republic, Italy and Spain and less often with those in Germany. The pattern of flooding in northern Switzerland and the Czech Republic seem to be rather similar, although the individual flood events do not match. This comparison of flooding patterns in different European countries suggests that changes in large scale atmospheric circulation are responsible for the flood frequency fluctuations.
\end{abstract}

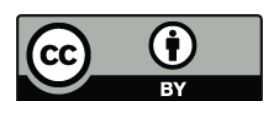

Correspondence to:

P. Schmocker-Fackel

(petra.schmocker-fackel@alumni.ethz.ch)

\section{Introduction}

Large floods occurred in northern Switzerland in 1977, 1978, 1999, 2005 and 2007. This flood-rich period was preceded by a period with relatively few floods (1940-1970) (Schmocker-Fackel and Naef, 2010). Another accumulation of large flood events in this region was observed in the second half of the 19th century (Rötlisberger, 1991). Can we identify other periods of high or low flood frequencies during the last 500 years? How does the recent flood-rich period fit in with this context? And is it possible to explain flood frequency fluctuations with generalized climatic indices?

To answer these questions, long flood time series are needed. Therefore, we included historical information about floods back to 1500 in our analysis. In Switzerland, detailed descriptions of floods which occurred prior to runoff measurements exist. Hächler (1991) and Rötlisberger (1991) collected data on such historical floods and Pfister (1984 and 1998) used historical floods as one parameter in more extensive climatic studies. In numerous case studies, historical floods have been used to extend the measured annual flood series to improve design flood estimations (e.g. Gees, 1997; Schaub et al., 1990). We collected the historical flood time series of 14 catchments in northern Switzerland. We always referred to more than one, or even all, time series in our interpretations to minimise the problem of possibly incomplete, erroneous and inhomogeneous historical flood time series. We also address the problem of comparing historical data with current discharge measurements.

Records of historical floods have been used to study changes in the flood frequencies of European rivers during recent centuries or even the whole millennium and have been related to climatic parameters (e.g. Camuffo and Enzi, 1995; Benito et al., 2003; Glaser and Stangl, 2004; Glaser, 2008; Sturm et al., 2001). A good overview over European

Published by Copernicus Publications on behalf of the European Geosciences Union. 
historical hydrology is given by Brázdil et al. (2006a). We compare Swiss flooding frequencies with those of other European rivers, and finally, discuss some theories about possible causes for the flood frequency fluctuations.

\section{Methods}

\subsection{Historical flood information}

Historical records, such as chronicles, diaries, letters or parish chronicles often mention floods and the damage caused by them. These records allow the reconstruction of the flood distribution over many centuries and contain valuable information about magnitude, formation and development of floods. Good summaries of how to use historical flood data are given by Bayliss and Reed (2001), Brázdil et al. (2006a) and Glaser and Stangl (2004).

Historical records have some limitations, since historical flood series may not be complete and may be partly incorrect (e.g. contain dating errors). And the written sources are often subjective (Glaser and Stangl, 2004) and vary in their accuracy and information content. Additionally, long flood time series are often inhomogeneous. Possible sources of inhomogeneity in long flood time series are changes in the quality of historical data sources, increases in damage potential with time and man-made or natural changes in the river flow capacity, e.g. sediment accumulation or erosion (Camuffo and Enzi, 1996) or the construction of dams. This can result in large uncertainties when interpreting single time series, but this can be overcome to some extent by looking at several time series together.

Details of floods tended to be recorded, if substantial damage occurred. However, each river has its own discharge threshold, which often changes over time, above which damage occurs at a given site. These thresholds depend on the river channel capacity and the damage potential along the river. Therefore, the frequencies of flood damage vary from river to river, so that the absolute number of floods recorded in the different sources cannot be compared for different catchments. However periods when there was frequent or little flooding can be compared.

\subsection{Historical data used and study sites}

Switzerland is a small country $\left(41285 \mathrm{~km}^{2}\right)$ in Western Europe with large climatic differences due to the Alpine mountain range which runs from west to east across Switzerland. North of the Alps, a temperate middle European climate dominates, while the climate south of the Alps is subMediterranean.

In our study, historical floods were compiled from the WSL historical and recent flood damage databases (Hilker et al., 2009; Rötlisberger, 1991), the Weikinn compilation (Weikinn, 1958 to 2002) and data from Gees (1997), Hächler (1991), Pfister (1984, 1998) and Schaub et al. (1990). For

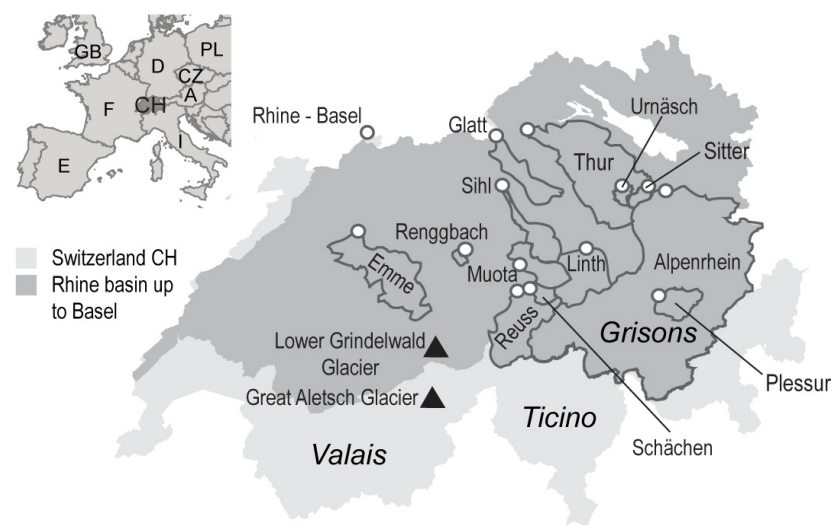

Fig. 1. Location of 14 catchments investigated and the geographical names used in this study.

the time period after 1500 , the historical data was sufficient to include 14 catchments into the analysis. These catchments are all situated in northern Switzerland, either in the Alps or in the Swiss Plateau (Fig. 1). The largest catchment is the Rhine catchment up to Basel $\left(35924 \mathrm{~km}^{2}\right)$, which drains most of northern Switzerland as well as parts of Austria and Germany, the smallest is the Renggbach in central Switzerland $\left(12 \mathrm{~km}^{2}\right)$. An event was counted as a flood if the name of a river and flood damage caused by the river were mentioned explicitly.

If a flood occurred in more than three catchments at the same time and caused extensive damage, it was classified as a large-scale flood. We found records of over 400 historical flood events in the 14 catchments. More than 100 affected more than one catchment and we classified 48 of them as large scale flood events. In the larger catchments of our study, floods are mainly caused by large-scale rainfall events with lower rainfall intensities but long duration. In addition, high water levels in the pre-alpine lakes after extensive snow melt influence flood formation in the Rhine River. In small catchments with limited storage capacities of soil and geology like the Renggbach, convective rainfall events of limited spatial extent but high rainfall intensities produce large floods. In the medium sized catchments Urnäsch, Sitter and Schächen both event types can cause floods. For these catchments, it would have been interesting to differentiate between the two triggering mechanisms but this was not possible due to insufficient information in the historic data.

\subsection{Merging historical flood information and discharge measurements}

Direct runoff measurements provide more reliable information about the flood history of a river than written, descriptive records from different archives. However, even the longest time series in Switzerland for the Rhine River in Basel started only in 1808 (Ghezzi, 1926). For the other 
Table 1. Hydrologic parameters of the 14 catchments used in this study and the discharge thresholds above which a discharge is defined as a flood comparable to the historic floods.

\begin{tabular}{|c|c|c|c|c|c|c|c|c|}
\hline \multirow[t]{3}{*}{ Catchment, Station } & \multirow{3}{*}{$\begin{array}{r}\text { Area } \\
{\left[\mathrm{km}^{2}\right]}\end{array}$} & \multirow{3}{*}{$\begin{array}{r}\text { Discharge } \\
\text { measured } \\
\text { since }\end{array}$} & \multicolumn{3}{|c|}{ Annual flood discharge } & \multicolumn{3}{|c|}{ Flood discharge threshold $\left[\mathrm{m}^{3} / \mathrm{s}\right]$} \\
\hline & & & $\mathrm{Ma}$ & imum & Mean & & & \\
\hline & & & {$\left[\mathrm{m}^{3} / \mathrm{s}\right]$} & {$\left[\mathrm{m}^{3} / \mathrm{s} \mathrm{km}^{2}\right]$} & {$\left[\mathrm{m}^{3} / \mathrm{s}\right]$} & HQ10 1 & Same frequency ${ }^{2}$ & Estimated \\
\hline Alpenrhein, Diepoldsau & 6123 & 1919 & 2665 & 0.44 & 1357 & 1958 & 1560 & - \\
\hline Emme, Emmenmatt & 443 & 1909 & 513 & 1.16 & 218 & 325 & 280 & - \\
\hline Glatt, Rümlang & 302 & 1948 & 93 & 0.31 & 39 & 70 & 67 & - \\
\hline Linth, Mollis & 600 & 1914 & 402.4 & 0.67 & 195.5 & 262 & 275 & - \\
\hline Muota, Ingenbohl & 316 & 1917 & 425 & 1.34 & 169 & 244 & 285 & - \\
\hline Plessur, Chur & 263 & 1930 & 90 & 0.34 & 50 & 71 & 90 & - \\
\hline Renggbach & 12 & - & $80-120^{3}$ & $6.5-9.6^{3}$ & - & - & - & - \\
\hline Reuss, Seedorf & 832 & 1904 & 735 & 0.88 & 308 & 454 & 478 & - \\
\hline Rhein, Basel & 35924 & 1808 & 5090 & 0.14 & 2839 & $3700^{4}, 3800^{5}$ & 3600 & 3600 \\
\hline Schächen, Bürglen & 109 & 1930 & 165 & 1.51 & 35 & 62 & 45 & - \\
\hline Sihl, Zürich & 336 & 1919 & 340 & 1.01 & 146 & 244 & 260 & - \\
\hline Sitter, Appenzell & 74 & 1908 & 195 & 2.63 & 80 & 117 & 128 & - \\
\hline Thur, Andelfingen & 1696 & 1903 & 1130 & 0.67 & 586 & 818 & 720 & 770 \\
\hline Urnäsch,Hundswil & 64 & 1961 & 120 & 1.86 & 65 & 104 & 118 & - \\
\hline
\end{tabular}

${ }^{1}$ Flood discharge with 10-year return period.

2 Same frequency of floods in measurement period as in historical period 1750-1900.

${ }^{3}$ Hydraulically reconstructed discharge of largest flood event in 20th century (VAW, 1995).

${ }^{4}$ After Jura lake correction.

5 Before Jura lake correction.

rivers, measurements commenced at the earliest in the beginning of the 20th century (FOEN, 2007).

Sometimes, historical sources contain such a wealth of information about river bed geometry and historical water levels that it is possible to estimate the flood discharge through hydraulic calculations (e.g. Naulet et al., 2005; Macdonald et al., 2006; Schaub et al., 2001). Then historical time series can be directly compared with measured discharge records. However, in most of our catchments, data was too sparse to use this approach.

To use the relatively short series of discharge measurements, a way had to be found to merge them in a consistent way with the historical flood information. To this purpose, they have to be converted in series of discrete flood events. In the historical series, floods are recorded, when they cause damage. In the continuous records, a threshold value has to be defined, above which a flood is used in the discrete series. Sturm et al. (2001), for example, used the mean yearly flood plus one or two standard deviations. However, too many floods were selected with this approach in our data.

To assess the sensitivity of the threshold value, we tested three different approaches (see Table 1):

First, the threshold was estimated by comparing the historical flood series with early discharge or water level measurements. This was possible for the Rhine in Basel and the Thur in Andelfingen, due to the good data situation (see col- umn "Estimated" in Table 1). In the second approach, the 10yearly flood (HQ 10, calculated according DVWK, 1999) was used as threshold (column "HQ10"). And finally, we assumed that the average numbers of floods in the period of measurement is the same as in the period from 1750 to 1900 in the historical record. The threshold value was selected to yield the same average numbers of floods in the period of measurement (column "Same Frequency").

Figure 2 illustrates for the annual flood series of the Rhine in Basel from 1808 to 2007 how historical data relate to runoff measurements. Years with recorded flood damage are marked with a star. The thresholds determined with the three methods described above are also indicated. From 1750 to 1900,18 flood events caused damage. This corresponds to 13 flood events since 1900 and a discharge threshold of $3600 \mathrm{~m}^{3} / \mathrm{s}$ according to Method "Same frequency". In Sect. 3.1 the differences between the three methods will be discussed in more detail. For the determination of periods rich and poor in floods (Sect. 3.2) as well as for the climate (Sect. 3.3) and European (Sect. 3.4) comparisons only method "Same frequency" was used.

In the first Jura Water Correction J1 between 1868 and 1891, the Aare, a Rhine tributary, was redirected into the three large lakes Biel, Neuchâtel and Murten, which now serve as equalizing reservoirs (Vischer, 2003). This resulted in a shift in flood frequency as shown in Table 1 and Fig. 2. 


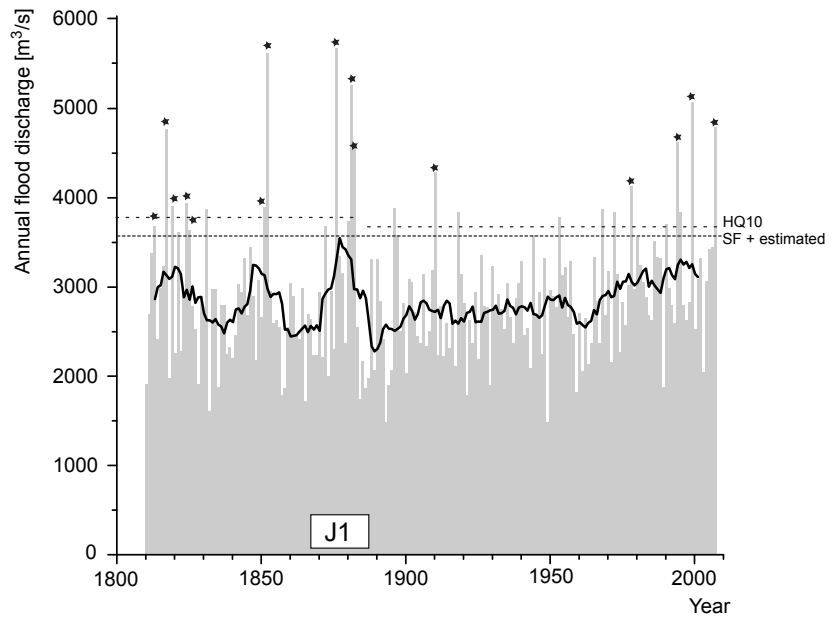

Fig. 2. Annual flood series of the Rhine river in Basel between 1808 and 2007 (grey bars) and its 11-year running mean (black line). Years with recorded flood damage are marked with stars. Horizontal lines correspond to the thresholds estimated with different methods defining a significant flood ( $\mathrm{SF}=$ same frequency method). The HQ10 discharge was estimated separately for the time before and after the first Jura water correction (J1). Data from FOEN (2007) and Ghezzi (1926).

Based on the work of Margot et al. (1991) effects of flood protection measures and the construction of large reservoirs were also considered in the other catchments (Fig. 3).

Historical time series are not homogeneous. We therefore never used flood series of single catchments but always looked at several catchments simultaneously.

\section{Results}

\subsection{Hydrological evaluation of historic flood data}

Figure 3 shows the historic flood frequencies of the 14 catchments, combined with the flood frequencies determined from the annual flood series. Flood-rich periods alternate with periods of lower flood frequency in all catchments, independent of catchment size. The number of floods differs between the catchments, with several showing a recent increase in flood frequency in the range of earlier periods.

The estimated threshold discharge above which damage occurred along the Rhine and the Thur corresponds approximately to a discharge with a 10-year return period (HQ 10). Historical floods also correspond approximately to floods with a return period of 10 years in a further seven catchments.

For the Muota and the Plessur, the historical floods have return periods of 40 and 70 years, respectively. It seems that, in both catchments, only large floods caused damage and were therefore recorded.

The "Same frequency" method produces slightly more floods in the Schächen and significantly more floods in the
Alpenrhein than "HQ10" method. In the Alpenrhein, the "Same frequency" method produces floods with only a two year return period. Before the large river correction starting in 1892, the Alpenrhein was a braided river system transporting and accumulating large amounts of sediment and had only minimal river bank protection. Therefore, even small floods could cause damage.

The comparison between the "Same frequency" method and the "HQ10" method suggests that some of our time series contain only the very large floods while other series also contain smaller floods. For the series including also the smaller floods there might be the additional problem that the earlier the records, the fewer the small floods were recorded, resulting in an apparent increase of floods with time. Since our time series contain floods of very different reoccurrence probability we decided to use the "Same frequency" method only for further analysis.

Figure 4 shows the number of historical floods in each catchment and their seasonal distribution. Summer and fall floods (June to October) dominate in all catchments. The percentage of winter floods (November to February) is below 10\%. Only in the Rhine at Basel and in the Thur do they comprise around $20 \%$ of all events. Spring floods (March to May) are also of minor importance. The seasonal distribution of flood frequencies has changed little during the last 500 years.

\subsection{Periodicities of flood frequency in Switzerland}

In Fig. 5a, the 10- and 30-year moving sums of all flood events per year at the 14 catchments are shown, with events that occurred in more than one catchment counted only once. Large-scale flood events in the whole of Switzerland are also shown. The apparent increase in flood events over time is probably mainly the result of more information about flood damage with time, the fluctuations within the time series cannot be explained by incomplete data.

Figure 6a shows the flood-rich decades for each catchment separately. During flood-rich decades more floods occurred than the mean number of floods per decade for the period 1700 to 2000 plus one standard deviation. Likewise, flood-rich periods overlapping two decades were identified from the 10-year running mean of observed flood frequency. From 1500 to 1700 , flood-rich decades could only be identified visually. Figure $6 \mathrm{~b}$ shows how many catchments in each decade experienced an above average number of floods.

Based on the data displayed in Figs. 5a and 6, periods of low and high flood frequency in northern Switzerland were identified. Four periods with peaks in flood frequency ( $\mathrm{P} 1$ to P4) and four periods with lows in flood frequency (L1 to L4) are discussed in more detail below. 

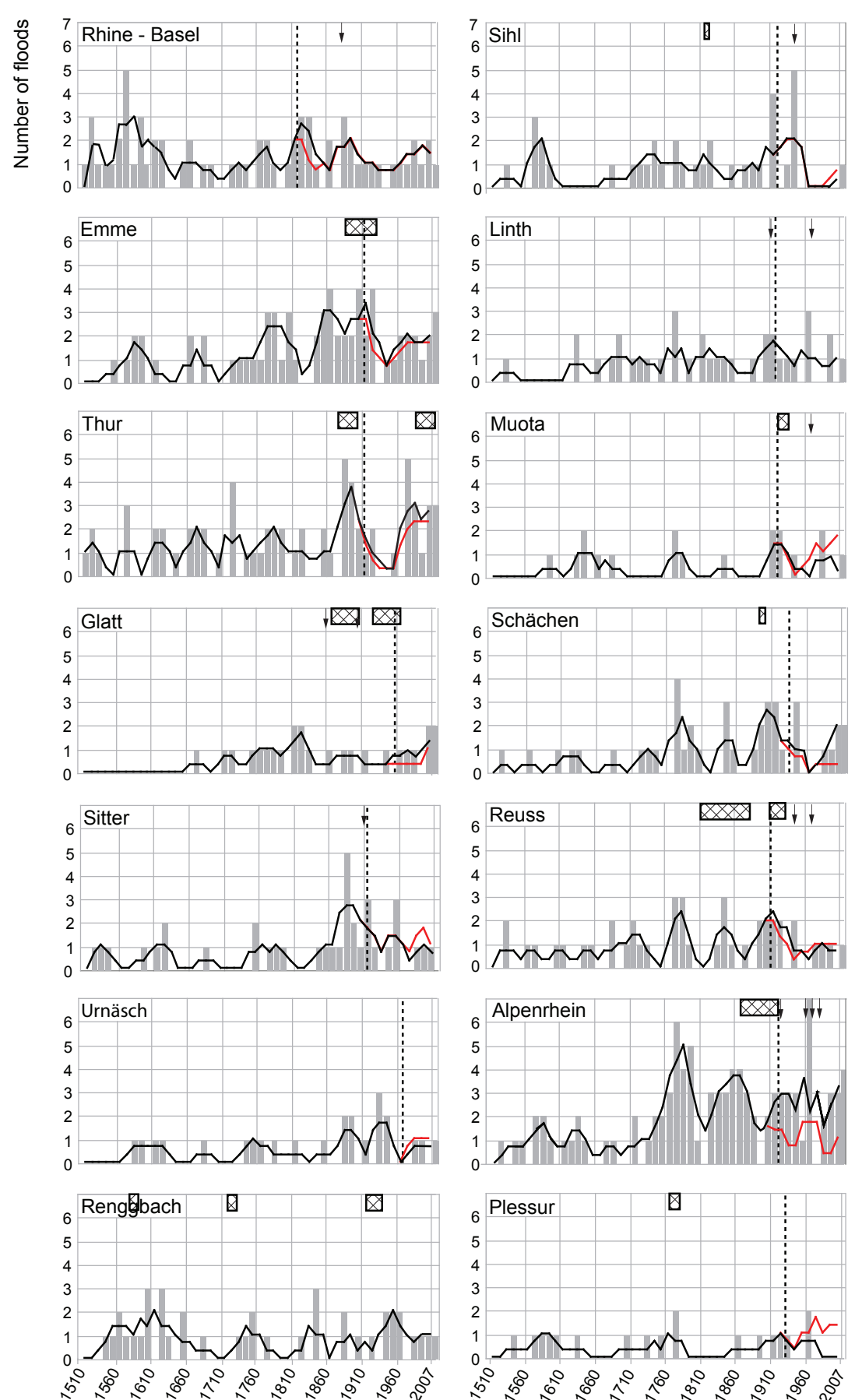

50.50

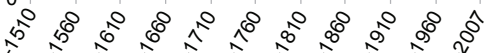

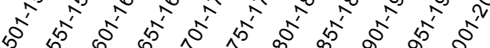

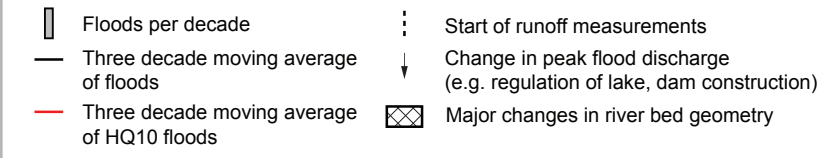

Fig. 3. Frequencies and three decadal mean running flood frequencies for 14 catchments in northern Switzerland. For the period with runoff measurements, different methods were used to define a flood (see Sect. 2.3). Also shown are changes in the river or catchments that influence flood damage and/or flood discharge. 


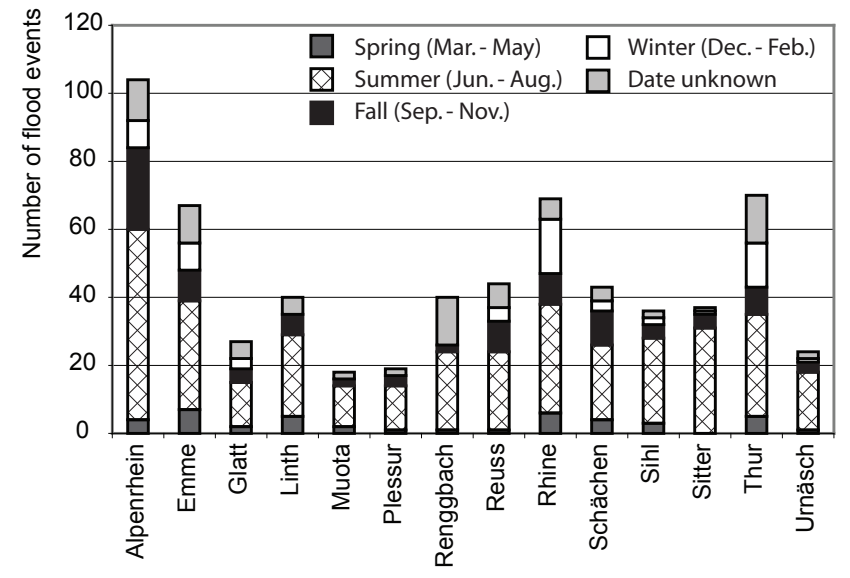

Fig. 4. Seasonal distribution of historic flood events for the period 1500-2007 in the 14 catchments studied. Summer floods dominate in all catchments.

\subsubsection{0-1560 (Low 1)}

This was a period of low flood frequency in northern Switzerland. According to Brázdil et al. (1999), 1506 to 1559 was an exceptional long period of low flood frequency for the Rhine in Basel. The apparent absence of floods in some catchments can partly be ascribed to missing data.

\subsubsection{0-1590 (Peak 1)}

During this period, flood frequency peaked especially in the large north alpine catchments Rhine, Thur, Emme and Sihl, as well as in the Alpenrhein in Grisons. In 1566 and 1570 there were catastrophic floods caused by extreme summer precipitation over large areas of long duration, accompanied by high lake-water levels due to extensive snow melt. Although the four neighbouring alpine catchments Muota, Schächen, Linth and Reuss in Central Switzerland also experienced some floods during this period, flood frequencies do not appear to have been higher. This, however, may well be due to missing data.

\subsubsection{0-1740 (Low 2)}

Especially between 1640 and 1720 there were exceptionally few floods throughout Switzerland. The total number of flood events in northern Switzerland was very low during this period, as were the number of large-scale flood events and flood-rich decades (Figs. 5a and 6b). In the 1690s there seem to have been only two small flood events and none of our catchments had a flood rich decade. Pfister (1999) found no historic evidence of any catastrophic floods between 1641 and 1706 in the Alpine region and maintains that this finding cannot be explained by missing data alone.

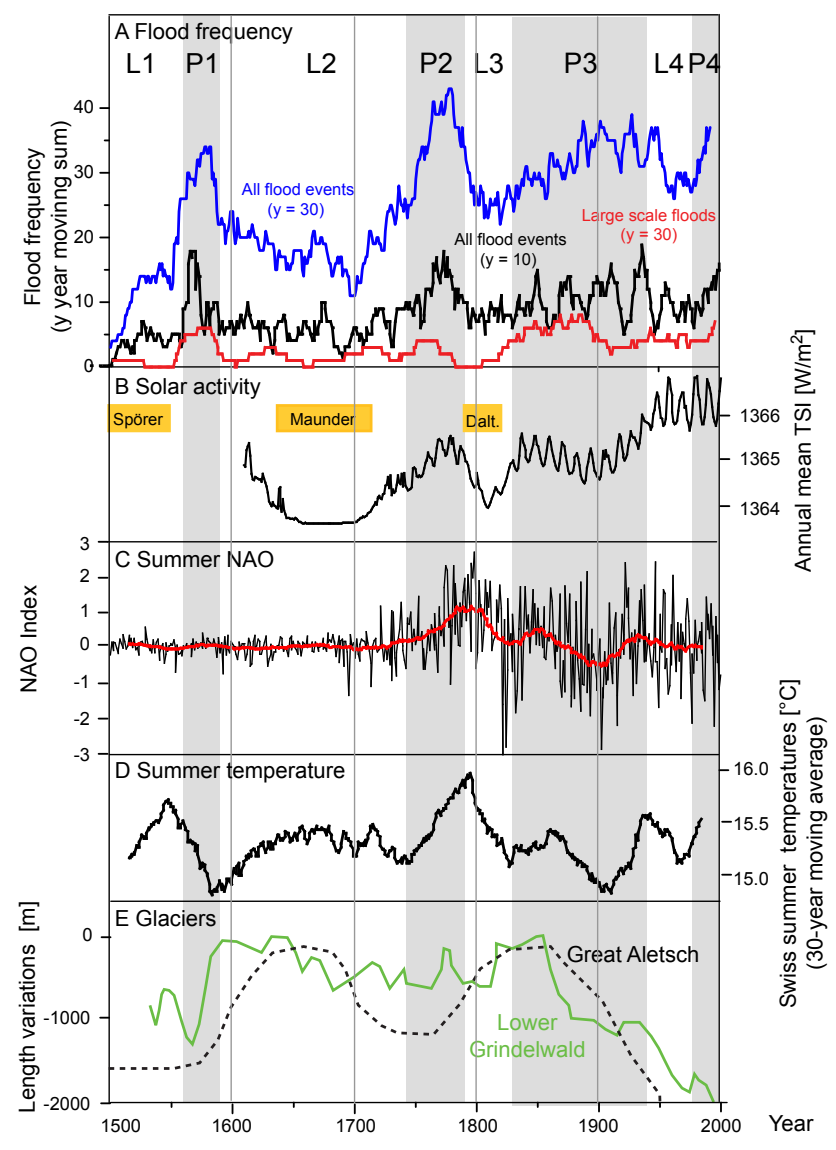

Fig. 5. Frequency of flood events in the 14 Swiss catchments and catastrophic events throughout Switzerland. P1-P4 are periods with many floods and L1-L4 with few floods in northern Switzerland (A). Also shown are the Spörer, Maunder and Dalton periods of low solar activity and the total solar irradiance TSI from Lean (2004) (B). The reconstructed yearly summer NAO values (black) and the 30-year moving average (red) are from Luterbacher et al. (1999 and 2002a) (C), the reconstructed Swiss summer temperatures (D) are from Casty et al. (2005) and the advances and retreats of the Lower Grindelwald and the Great Aletsch glacier are from Holzhauser and Zumbühl (1999) (E).

\subsubsection{0-1790 (Peak 2)}

This is the period with the highest flood frequency in our records. In the 1760s eleven of the 14 catchments had a flood-rich decade and two catastrophic floods occurred in 1762 and 1764. For the flood in July 1762, damage was recorded in eight of the 14 catchments. Only the three smallest catchments Renggbach, Urnäsch and Sitter did not seem to have had a peak in flood frequency in the 1760 s, but they did in the 1740s.

\subsubsection{0-1810 (Low 3)}

Between 1790 and 1810, another short period of low flood frequency occurred in northern Switzerland. 


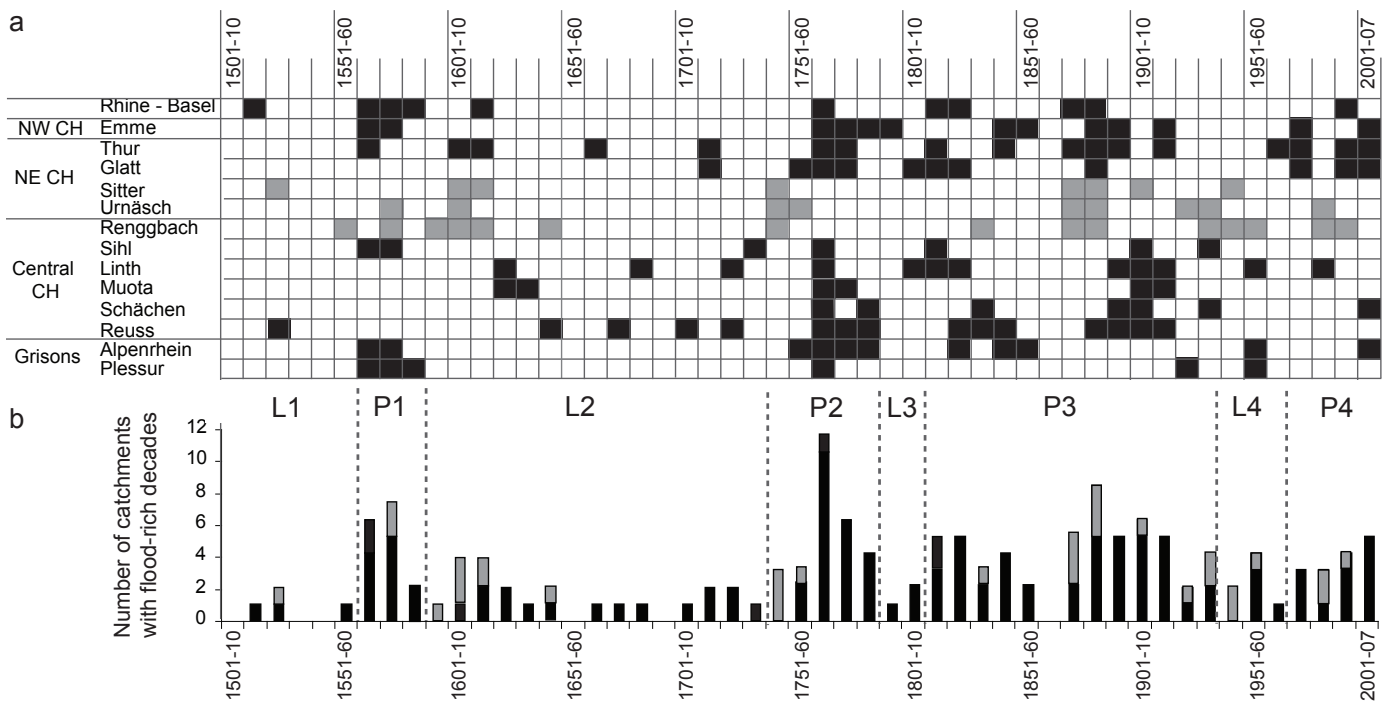

Fig. 6. Flood-rich decades in our 14 catchments (black: flood-rich decade in large catchments caused by long duration rainfall events, grey: small catchments where convective rainfall events are important). Also shown are the periods rich (P1-P4) and poor (L1-L4) in floods in northern Switzerland, as defined in this study (vertical dotted lines).

\subsubsection{0-1940 (Peak 3)}

During this period, a very long and heterogeneous peak in flood frequency was observed throughout Switzerland. Most catchments had several peaks during this period. The annual flood series of the Rhine (Fig. 2), for example, contains peaks with markedly increased flood frequency around 1820, 1850 and 1870. Again two sub-periods can be distinguished, one before and one after 1890. Catastrophic flood events were more frequent between 1830 and 1890, while there was a peak in all flood events after 1890. The apparent increase in the number of small flood events towards the end of this period might be partly due to more data being available later in this period (e.g. first continuous runoff measurements).

\subsubsection{0-1970 (Low 4)}

In this period there were few floods in northern Switzerland, especially in Central and NE Switzerland (SchmockerFackel and Naef, 2010). The only places where several floods occurred in the 1940s and 50s, are the three small catchments, and the Alpenrhein and the Plessur in the Grisons.

\subsubsection{Since 1970 (Peak 4)}

Since the 1970s, the flood frequency in most catchments has increased, especially in NE Switzerland and, since the 1990s, also in Central Switzerland (Schmocker-Fackel and Naef, 2010). However, the flood frequencies observed during the past 40 years in our 14 catchments are still within the range of or lower than those observed during the last five centuries.

\subsection{Can we explain the fluctuations in observed flood frequency?}

According to the reviewed literature and our study, the flood frequencies in Europe have changed at intervals of 30-100 years during the last 500 years or according to Glaser and Stangl (2004) even within the past millennium. Knox (2000) and James (1993) showed that the magnitudes and recurrence frequencies of floods can change abruptly. However, the mechanisms responsible for these changes are not yet clear (Redmond et al., 2002; Benito et al., 2004 and studies referenced in there).

Some authors tried to connect the changes in flood frequencies with some generalized parameters like climate periods, solar activity, the north Atlantic oscillation (NAO), mean air temperatures or length variations of glaciers. Glaser (1998) for example, claims a connection between flood frequencies in Central Europe and the onset and end of the little Ice Age (1430-1850). High flood frequencies in the Mediterranean basins of Spain (Benito et al., 2003), the Yangtze River (Jiang et al., 2005) and the Upper Mississippi River (James, 1993) also correspond to the initial and final decades of the medieval warm period and the Little Ice Age. In Switzerland, high flood frequencies could also be observed in the second half of the 15th (Rötlisberger, 1991) and in the 19th century, at the onset and end of the little ice age.

Vaquero (2004) found a relationship between low flood activity on the Iberian Peninsula and the Maunder Minimum of solar activity, suggesting that solar activity may induce climatic variations responsible for the flood frequency oscillations. In Switzerland, the periods L1, L2 and L3 of reduced flooding correspond to the end of the 
Spörer Minima (1420-1550), the Maunder Minima (16451715) and the Dalton Minima (1790-1820) of solar activity (Fig. 5b). There have been exceptionally few floods during the late Maunder Minimum (1675-1715). However, flood frequency was low in the 20th century (L4) when solar activity was high (Solanki et al., 2004; Lean, 2000). During the first half of the Spörer Minimum, several catastrophic floods occurred in Switzerland in the 1470s and 1480s (Rötlisberger, 1991). Camuffo and Enzi (1995) found little if any relationship between solar activity and the flood frequencies of the Po, Tiber and Adige rivers in Italy during the past 2000 years including the Wolf and Spörer Minima and Pauling and Paeth (2007) found no clear connection between winter precipitation extremes in Central Europe and solar, volcanic or anthropogenic forcing.

Floods in English and Welsh upland catchments seem to be more frequent during negative North Atlantic Oscillation NAO (Macklin and Rumsby, 2007). However, we did not find a relation between our Swiss flood data and the reconstructed summer NAO indices of Luterbacher et al. (1999 and 2002a), or the reconstructed winter NAO values of Trouet et al. (2009) (Fig. 5c). The forcing of the NAO in the Alpine region is weak (Casty et al., 2005), and NAO phases do not correlate with Alpine precipitation (Frei et al., 2000). Bouwer et al. (2006) also found no strong relationship between winter river discharges and the NAO index in northern Europe.

Global mean air temperatures have increased since 1900. This might lead to more frequent flooding due to a higher moisture content of the atmosphere (IPCC, 2008) or due to a higher snowline (Allamano et al., 2009). However, no clear trend could be identified in the measured flood series in Switzerland (Schmocker-Fackel and Naef, 2010) or Europe (e.g. Mudelsee et al., 2003), although Brisan et al. (2005) detected shifts in seasonal runoff in Switzerland in the last decades especially in the alpine and glaciated catchments. For the last 500 years we did not find a direct relationship between mean air temperatures (winter or summer) (Fig. 5d) and flood frequency. However, the air temperature time series as well as the variations in length of Swiss glaciers (Fig. 5e) indicate that the periods P1 to P4 of high flood frequency in Switzerland correspond to periods of rapid climatic change in the Alpine region.

Obviously, it is not possible to explain the observed changes in flood frequencies in Switzerland in the last 500 years with single generalized climatic parameters, as the reasons for these changes are too complex. More insight into this complexity allows approaches that look into the relation between flood frequencies and large scale atmospheric circulation. For the last 500 years, Luterbacher et al. (2002b) reconstructed sea level pressure grids for Central Europe in monthly (after 1659) and seasonal (before 1659) temporal resolution. This coarse temporal resolution does not allow the investigation of synoptical systems responsible for the individual flood events. However, they allow the determination of large-scale atmospheric circulation patterns, which might favour the occurrence of synoptical systems causing floods (Hirschboek, 1988; Jacobeit et al., 2004). For the last 500 years, the relationship between flood frequency in central Germany (e.g. rivers Main, Rhein, Elbe and Weser) and large scale atmospheric circulation was investigated in several studies (Sturm et al., 2001; Jacobeit et al., 2003 and 2004; Mudelsee et al., 2004; Wanner et al., 2004). These studies showed that during flood rich periods flood favouring circulation modes occurred more frequent. Jacobeit et al. (2003) for example found that most winter flood events occurred during zonal circulation. However, two circulation modes characterised by an Atlantic low and Russian high pressure centre played an important role during flood rich periods as well. Summer floods occurred more frequently during circulation modes with troughs over the British Isles (Jacobeit et al., 2004). During the period 1926-2003, winter discharges of several rivers in northern Europe also seem to be significantly correlated with the frequency of westerly flow (Bowler et al., 2006) and for the 20th century summer floods in Central Europe could be linked to special atmospheric circulation patterns such as $\mathrm{Vb}$ tracks (Kundzewicz et al., 2005). Wanner et al. (2004) found that fluctuations in flood frequency in Central Germany during the last 500 years are probably due to changes in large scale circulation over the North-Atlantic European area. A second finding of these studies was that different circulation modes dominated during different flood rich periods of the same river. This might explain the fact that the periodicities of flood frequency between rivers or regions are sometimes in phase and sometimes they are not.

Using measurements from over 80 stream gauges and historical data, Schmocker-Fackel and Naef (2010) identified the largest flood events in Switzerland since 1850 and compared them with the associated flow direction over the Alps at the $500 \mathrm{hPa}$ pressure level from the Alpine weather statistics (MeteoSwiss, 1985 ${ }^{1}$ ). Three typical meteorological conditions could be identified: NW floods caused by north-westerly flow, affecting western and northern Switzerland, NE floods during north-easterly flow or changing flow directions including the $\mathrm{Vb}$ flood events, affecting northeastern and Central Switzerland and finally the S floods during southerly flow, affecting southern Switzerland (Valais, Ticino and Grisons) and sometimes through overlapping of precipitation to the north side of the Alps also Central and north-eastern Switzerland. During the last 150 years, the NE floods have been relatively evenly distributed over time. NW floods have occurred more frequently towards the end of the 19th century and since 1970, but were less frequent in the first seven decades of the 20th century. The frequency of precipitation overlapping from south of the Alps to northern Switzerland has also decreased since the 19th century. This might explain the low flood frequency during low 4 and

\footnotetext{
${ }^{1}$ MeteoSchweiz: Alpenwetterstatistik, Beschreibung der einzelnen Parameter, Abteilung Forschung, unpublished, 1985.
} 
Table 2. The catchments, data and methods used for a comparison of flood frequency on a European scale for the period 1560-1810. In all cases unless otherwise mentioned, we determined the periods rich and poor in floods.

\begin{tabular}{|c|c|c|c|c|c|}
\hline Region & No. & Catchments & Data available & $\begin{array}{l}\text { Method to } \\
\text { determine } \\
\text { periods rich } \\
\text { and poor in } \\
\text { floods }\end{array}$ & Data from \\
\hline $\begin{array}{l}\text { Northern } \\
\text { Switzerland }\end{array}$ & 1 & $\begin{array}{l}14 \text { catchments } \\
\text { of this study }\end{array}$ & & & \\
\hline $\begin{array}{l}\text { Southern } \\
\text { Germany }\end{array}$ & 2 & $\begin{array}{l}\text { Lech } \\
\text { Isar }\end{array}$ & $\begin{array}{l}\text { 31-year running flood } \\
\text { frequency }\end{array}$ & frequency $>5$ & Böhm and Wetzel, 2006 \\
\hline Czech Republic & 3 & $\begin{array}{l}\text { Vltava } \\
\text { Elbe } \\
\text { Ohre } \\
\text { Morava }\end{array}$ & $\begin{array}{l}\text { Decadal flood } \\
\text { frequencies }\end{array}$ & $\begin{array}{l}\text { more than one } \\
\text { SD from mean }\end{array}$ & Brázdil et al., 2006b \\
\hline \multirow[t]{2}{*}{$\begin{array}{l}\text { Northern and } \\
\text { Central Germany }\end{array}$} & 4 & Pegnitz & $\begin{array}{l}\text { Cumulated and filtered } \\
\text { flood data }\end{array}$ & Visually & Glaser, 1998 \\
\hline & $\begin{array}{l}5 \\
6 \\
7 \\
8 \\
9\end{array}$ & $\begin{array}{l}\text { Saale } \\
\text { Middle Elbe } \\
\text { Weser } \\
\text { Main } \\
\text { Middle Rhine }\end{array}$ & $\begin{array}{l}\text { Standardized 31-year } \\
\text { running seasonal flood } \\
\text { frequency }\end{array}$ & $\begin{array}{l}\text { more than one } \\
\text { SD from mean } \\
\text { determined by } \\
\text { authors }\end{array}$ & $\begin{array}{l}\text { Sturm et al., 2001; } \\
\text { Glaser and Stangl, } 2004\end{array}$ \\
\hline $\begin{array}{l}\text { Northern Italy } \\
\text { Central Italy }\end{array}$ & $\begin{array}{l}10 \\
11 \\
12\end{array}$ & $\begin{array}{l}\text { Adige } \\
\text { Po } \\
\text { Tiber }\end{array}$ & $\begin{array}{l}\text { Frequency distribution } \\
\text { of floods }\end{array}$ & visually & Camuffo and Enzi, 1995 \\
\hline $\begin{array}{l}\text { Spanish } \\
\text { Mediterranean } \\
\text { coastal area }\end{array}$ & 13 & $\begin{array}{l}10 \\
\text { Mediterranean } \\
\text { basins }\end{array}$ & $\begin{array}{l}\text { Absolute decadal } \\
\text { frequency of } \\
\text { catastrophic floods and } \\
\text { averaged decadal flood } \\
\text { frequencies }\end{array}$ & visually & $\begin{array}{l}\text { Barriendos and Martin-Vide, 1998; } \\
\text { Barriendos and Rodrigo, } 2006\end{array}$ \\
\hline $\begin{array}{l}\text { Spain Atlantic } \\
\text { Basins }\end{array}$ & 14 & $\begin{array}{l}\text { Tagus and } \\
\text { several other } \\
\text { Atlantic basins }\end{array}$ & $\begin{array}{l}\text { Averaged decadal flood } \\
\text { frequencies }\end{array}$ & visually & $\begin{array}{l}\text { Benito et al., 2003; } \\
\text { Barriendos and Rodrigo, } 2006\end{array}$ \\
\hline France & 15 & Drac and Isère & $\begin{array}{l}\text { Cumulated flood } \\
\text { number (data starting } \\
1600 \text { only) }\end{array}$ & visually & Barriendos et al., 2003 \\
\hline
\end{tabular}

the few large scale floods in the first seven decades of the 20th century in our 14 catchments in northern Switzerland. Due to limited data, it was not possible to extend such an analysis further back in time. For Switzerland, large-scale atmospheric flow classifications and flooding have not been compared so far. It might, however, be worthwhile doing so in future studies. These results suggest that changes in atmospheric circulation are responsible for the changes in flood frequency in Switzerland and Europe. Frei et al. (2000) also suggest an interrelationship between changes in extreme precipitation in Switzerland and large scale atmospheric circulation. However, the mechanisms responsible for these decadal scale changes in atmospheric circulation are not yet understood and subject to ongoing climatologic research.

\subsection{Swiss flood cycles in the European context}

To find out whether the observed fluctuations in flood frequency in northern Switzerland correspond to fluctuations found in other parts of Europe, we compared our results with those obtained for the other European rivers and regions listed in Table 2 according to the following rules:

Whenever possible, periods were classified as rich or poor in floods according to similar methods to those used in this study, or according to the respective authors' classifications. However, if the data did not allow such a classification, periods rich and poor in floods had to be estimated visually, and therefore rather subjectively.

We used the time intervals described above for northern Switzerland. For the catchments and regions where the time intervals were different, we allocated the dominant mode, 


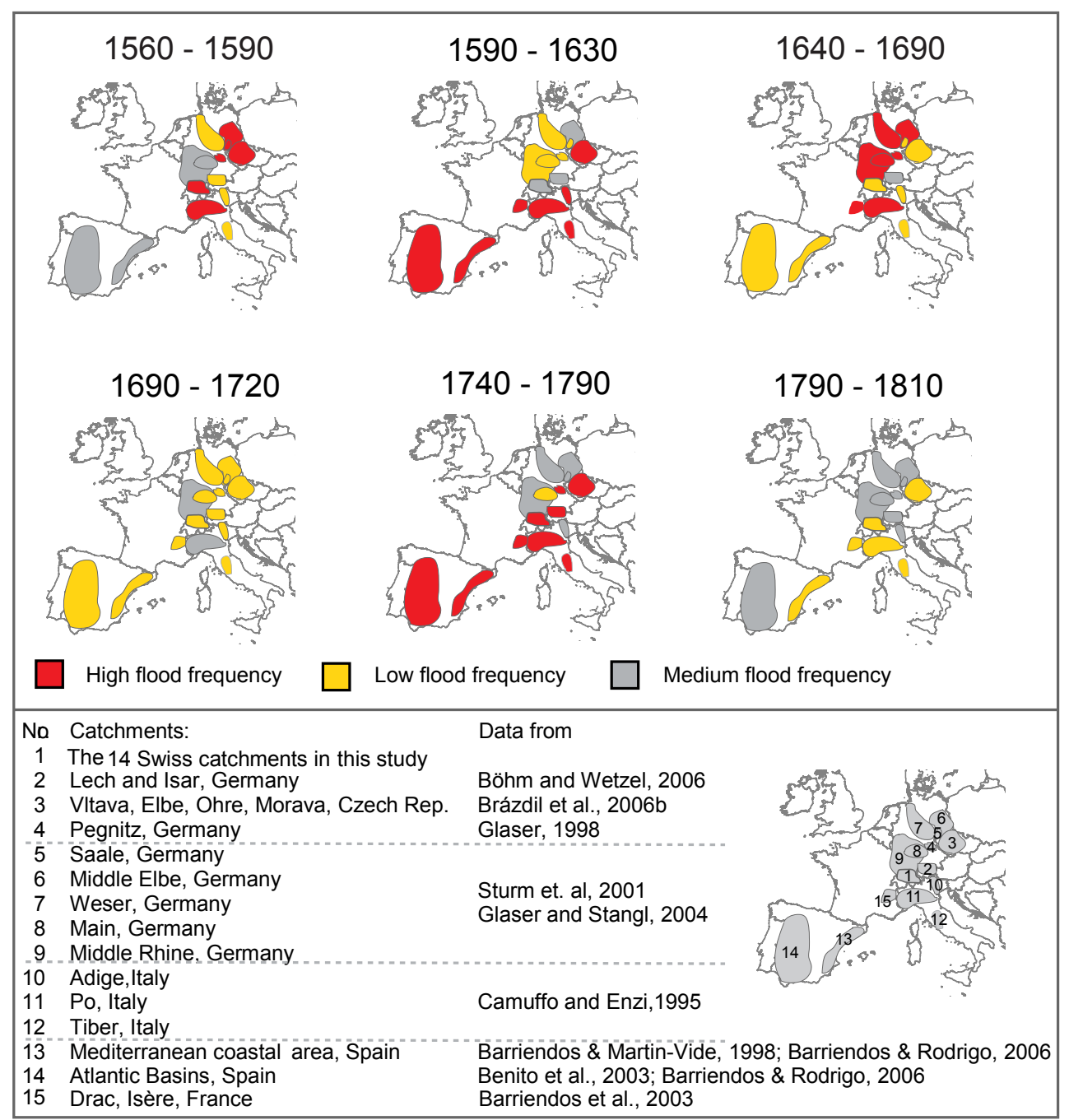

Fig. 7. Schematic presentation of spatial and temporal distribution of periods with very frequent and less frequent flooding in Europe for selected periods between 1560 and 1810 .

taking into account that a flood-rich period may have started a little earlier or later than in northern Switzerland. Where sufficient data are available, such deviations are mentioned in the text.

In Fig. 7, the flood frequencies for different catchments in Europe for selected periods between 1560 and 1810 are shown. During period 1560-1590 floods were frequent in northern Switzerland. High flood frequencies occurred in the Po River in northern Italy (Camuffo and Enzi, 1995), in the Czech Republic (Brázdil et al., 2006b) and in the Middle Elbe and the Saale in northeastern Germany (Sturm et al., 2001). Böhm and Wetzel (2006), however, found lower than average flood frequencies in the Lech and Isar rivers in Southern Germany during this period. As did Sturm et al. (1991) in the Weser in northern Germany and Camuffo and Enzi (1995) in the Adige and Tiber rivers in Italy.
Between 1590 and 1630 the eastern and southern European catchments had high flood frequencies. Benito et al. (2003) identified this period $1580-1620$ as an "intense, prolonged phase with hydrologic extreme events doubling mean values in basins of the Mediterranean Spanish coast", whereas northern Switzerland and Germany experienced a quieter period.

Between 1640 and 1690, few floods occurred in northern Switzerland, the Czech Republic, Spain and the Adige and Tiber catchments in Italy. On the other hand, most German catchments as well as the River Po had high flood frequencies.

From 1690 to 1720 , the flood frequency was low in all the European catchments used in this comparison. Barriendos and Rodrigo (2006) found no large floods in the two decades 1661-1670 and 1711-1720 in the Iberian Peninsula. 
During the second Swiss peak in flood frequency between 1740 and 1790, the spatial European distribution of flood frequencies resembles those of period 1590-1630. From 17901810, few floods were recorded in Europe with the exception of Spain. In several Atlantic basins in Spain a peak in flood frequency occurred between 1790 and 1800 (Benito et al., 2003). The flood frequency distribution in northern Switzerland seems to correspond better to that in Spain, Italy and the Czech Republic than to that in Germany.

It is interesting to note that, during three of the six investigated time periods, flood frequencies in Europe appear to follow a NW and a SE pattern: During the periods 1590-1630 and $1740-1790$, few or a medium number of floods occurred in the NW part of Europe but took place in SE. During the period 1640-1690 the pattern was reversed with the exception of the Po catchment, and during two periods $1690-1720$ and 1790-1810, very little flooding occurred in most catchments.

For the periods after 1810, the pattern of flood frequency is much more heterogeneous, in Switzerland as well as in Europe, which is why the comparison should be at decadal time intervals. With the data available, such a comparison could be only made with the four catchments Vltava, Elbe, Ohre and Morava in the Czech Republic (Brázdil et al., 2006b). For the Czech catchments, we determined the flood-rich decades with the method we used in this study (see also Table 2). In Fig. 8, the percentages of catchments with flood-rich decades for northern Switzerland and the Czech Republic are displayed for the period 1500 to 1920.

The flood frequency cycles in Switzerland and the Czech Republic seem to be quite similar. Only during peak 2 were slight differences, with a peak in flood frequency in the Czech Republic in the 1740s and one in Switzerland in the 1760s. There has been a recent increase in flood activity after a relatively quiet period, with disastrous floods in the Czech Republic in 1997, 1998 and 2002 (Brázdil et al., 2006b). This corresponds to a similar increase in northern Switzerland, with large floods in 1999, 2000, 2005 and 2007 after the quiet period 1940-1970 (Schmocker-Fackel and Naef, 2010).

However, while the periods with high flood frequencies correspond in Switzerland and the Czech Republic, the individual flood events do not. This holds true for recent decades as well as for the 16th and the 19th century. Brázdil et al. (1999) compared flood events in the 16th century in the Rhine (Basel) with the Vltava and Upper Elbe in the Czech Republic and found no floods that occurred at the same time in both countries. Using the Czech data, we also found no individual flood events that matched with any flood in our 14 catchments. During the maximum flood activity in the Czech Republic in the 19th century, there was a prevalence of winter floods (Brázdil et al., 2006b), while in Switzerland summer floods always dominated. This phenomenon was also observed in Spain, where there is a clear coincidence between periods with high flood frequencies in the Mediterranean and Atlantic watersheds, although autumn

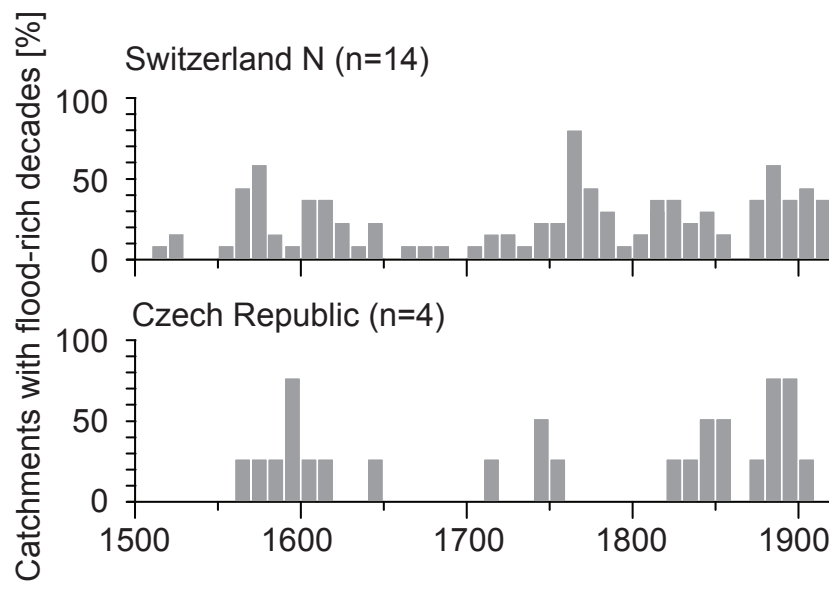

Fig. 8. Comparison of flood frequencies between Switzerland and the Czech Republic (data from Brázdil et al., 2006b), for the period 1500-1920.

and spring floods dominate in the Mediterranean watersheds and winter floods in the Atlantic watersheds (Benito et al., 2003).

Flood frequency cycles in the European rivers investigated are only partially in phase. Some reoccurring patterns of flood frequency, such as the NW-SE pattern in Europe, were found. But even in regions which were in phase, the floods did not occur on the same dates. However, these findings also suggest that changes in atmospheric circulation patterns on a decadal time scale are responsible for the flood frequency fluctuations.

\section{Summary and conclusions}

Since 1500, periods of higher flood frequencies have alternated in Switzerland with quieter periods. Active periods occurred between 1560 and 1590, around 1760 and in the 19th century. The recent increase in flood frequencies, starting in the 1970s is still in the range of formerly observed ones. Quiet periods were between 1630 and 1720, 1790 and 1810, and 1940 and 1970.

It is not possible to explain these variations with generalized climatic indices. For example, between 1500 and the 19th century, flood frequency was low in northern Switzerland during extended periods of low solar activity (Spörer, Maunder and Dalton Minima). Between 1700 and 1720 (Late Maunder Minimum), between 1790 and 1810 (Dalton Minimum), low flood frequencies also occurred in many other European countries. However, since 1810 flood frequency and solar activity no longer appear to correlate. In northern Switzerland, no correlation seems to exist between flood frequency and either reconstructed NAO indices or reconstructed temperatures.

A comparison with the flood patterns of other European rivers suggests that flood frequencies are not in phase over 
Europe but reoccurring spatial patterns of flood frequency do seem to occur. The flood frequencies in northern Switzerland are often in phase with those of rivers in Spain, Italy and the Czech Republic, but less with those in Germany. Flood frequency patterns appear to be similar in Switzerland and in the Czech Republic, although neither individual flood events nor the seasonal flood distribution match. It seems most likely that changes in atmospheric circulation patterns on decadal time scales are responsible for the spatially heterogeneous changes in flood frequency.

Atmospheric circulation patterns and flood frequencies in central Europe have been found to correlate (Jacobeit et al., 2003 and 2004; Mudelsee et al., 2004; Wanner et al., 2004), as have jet stream configurations and flooding frequency in North America (Knox, 2000). In Switzerland, different kinds of weather situations can produce large floods (SchmockerFackel and Naef, 2010). However, an analysis of circulation patterns and flood frequencies for Switzerland has not been done so far, but might yield interesting results. Analysis of flood frequency data from additional European countries like France, Great Britain and Austria could help to reconstruct changing atmospheric circulation patterns on a scale large enough to show flooding patterns in different parts of Europe.

Procedures for defining design floods assume that the reoccurrence probabilities of floods remain constant over longer periods. However, our study indicates that flood reoccurrence probabilities are not constant over time. Since 1500 three periods with high flood frequencies lasting between 30 and 120 years have occurred. This suggests that the current period with more floods in northern Switzerland, which started in the mid 1970s, might continue for some decades under natural climatic variation. The implications of such a behaviour, especially in statistical questions and problems, may be substantial (Koutsoyiannis and Montanari, 2007). Cohn and Lins (2005) even argue that the concept of statistical significance is meaningless when discussing such poorly understood systems.

To reduce the uncertainty in predicting the future frequencies of floods, the causes of the long-term changes in atmospheric circulation have to be better understood, together with the effects of the greater humidity of the atmosphere induced by global-warming (Frei et al., 2000).

Acknowledgements. This study was financed by the Swiss Federal Office for the Environment (FOEN) as part of the August 2005 flood analysis (Ereignisanalyse Hochwasser, 2005). We are grateful to the Hydrology division of FOEN and to SwissMeteo for supplying the necessary data for this study, and to Swisstopo for permission to use the digital general map of Switzerland (K606-01@2004). We thank Silvia Dingwall for editing our English.

Edited by: F. Laio

\section{References}

Allamano, P., Claps, P., Laio, F.: Global warming increases flood risk in mountainous areas, Geophys. Res. Lett., 36 , L24404, doi:10.1029/2009GL041395, 2009.

Barriendos, M. and Rodrigo, F. S.: Historical flood events in Spain, Hydrolog. Sci. J., 51, 5, 765-783, 2006.

Barriendos, M., Coeur, D., Lang, M., Llasat, M. C., Naulet, R., Lemaitre, F., and Barrera, A.: Stationarity analysis of historical flood series in France and Spain (14th-20th centuries), Nat. Hazards Earth Syst. Sci., 3, 583-592, doi:10.5194/nhess-3-5832003, 2003.

Barriendos, M. and Martin-Vide, J.: Secular climate oscillations as indicated by catastrophic floods in the Spanish Mediterranean coastal area (14th-19th centuries), Clim. Change, 38, 4, 473491, 1998.

Bayliss, A. C. and Reed, D. W.: The use of historical data in flood frequency estimation, CEH Tech. Report, 2001.

Benito, G., Lang, M., Barriendos, M., Llasat, C. M., Francés, F., Ourada, T., Thorndycraft, V. R., Enzel, Y., Bardossy, A., Coeur, D., and Bobée, B.: Use of systematic, palaeoflood and historical data for the improvement of flood risk estimation, Review of scientific methods, Nat. Hazards, 31, 623-643, 2004.

Benito, G., Díez -Herrero, A., and Fernández de Villalta, M.: Magnitude and frequency of flooding in the Tagus basin (Central Spain) over the last millennium, Clim. Change, 58, 171-192, 2003.

Böhm, O. and Wetzel, K. F.: Flood history of the Danube tributaries Lech and Isar, Hydrolog. Sci. J., 51, 5, 784-798, 2006.

Bouwer, L. M., Vermaat, J. E., and Aerts, J. C. H.: Winter atmospheric circulation and river discharge in northwerst Europe, Geophys. Res. Lett. 33, L06403, doi:10.1029/2005GL025548, 2006.

Brázdil, R., Glaser, R., Pfister, C., Dobrovolny, P., Antoine, J. M., Barreindos, M., Camuffo, D., Deutsch, M., Enzi, S., Guidoboni, E., Kotyza, O., and Schachez Rodrigo, F.: Flood events of selected European Rivers in the sixteenth century, Clim. Change, 43, 239-285, 1999.

Brázdil, R., Kundzewicz, Z. W., and Benito, G.: Historical hydrology for studying flood risk in Europe, Hydrolog. Sci. J., 51, 5, 739-763, 2006a.

Brázdil, R., Dobrovolny, P., Kakos, V., and Kotyza, O.: Historical and recent floods in the Czech Republic - Causes, seasonality, trends, impacts, in: Flood Risk Management Hazards, Vulnerability and Mitigation Measures, edited by: Schanze, J. et al., Springer, 247-259, 2006b.

Brisan, M. V., Molnar, P., Burlando, P., and Pfaundler, M.: Streamflow trends in Switzerland, J. Hydrol., 314, 321-329, 2005.

Camuffo, D. and Enzi, S.: The analysis of two bi-millennial series: Tiber and Po River floods, in: Climate Variations and Forcing Mechanisms of the Last 2000 years, edited by: Jones, P. D., Bradley, R. S., and Jourzel, J., NATO ASI Series, 141, Springer, 433-450, 1996.

Camuffo, D. and Enzi, S.: Climatic features during the Spörer and Maunder Minima, in: Solar output and climate during the Holocene, edited by: Frenzel, B., Paläoklimaforschung 16, Gustav Fischer Verlag, Stuttgart, 105-124, 1995.

Casty, C., Wanner, H., Luterbacher, J., Esper, J., and Böhm, R.: Temperature and precipitation in the European Alps since 1500, Int. J. Climatol., 25, 1855-1880, 2005. 
Cohn, T. A. and Lins, H. F.: Nature's style: Naturally trendy, Geophys. Res. Lett. S, 32(23), L23402, doi:10.1029/2005GL024476, 2005.

DVWK: Statistische Analyse von Hochwasserabflüssen, DVWKMerkblätter zur Wasserwirtschaft, 251, Deutscher Verband für Wasserwirtschaft und Kulturbau, 1999.

FOEN - Swiss Federal Office for the Environment: Hydrologisches Jahrbuch der Schweiz, Jahre 1913 bis 2007, Schweizerische Eidgenossenschaft, Bern, 2007.

Frei, C., Davies, H. C., Gurtz, J., and Schär, C.: Climate dynamics and extreme precipitation and flood events in central Europe, Integrated Assessment, 1, 281-299, 2000.

Gees, A.: Analyse historischer und seltener Hochwasser in der Schweiz - Bedeutung für das Bemessungshochwasser, Geographisches Institut der Universität Bern, Geographica Bernensia, G53, 1997.

Ghezzi, C.: Die Abflussverhältnisse des Rheins in Basel, Mitteilungen des Amtes für Wasserwirtschaft, 19, Bern, 1926.

Glaser, R.: Klimageschichte Mitteleuropas, 1200 Jahre Wetter, Klima, Katastrophen, 2nd Edn., 272 pp., 2008.

Glaser, R. and Stangl, H.: Climate and floods in central Europe since AD 1000: Data, methods, results and consequences, Surv. Geophys., 25, 485-510, 2004.

Glaser, R.: Historische Hochwässer im Maingebiet- Möglichkeiten und Perspektiven auf der Basis der historische Klimadatenbank Deutschland (HISKLID), in: Aktuelle und historische Hochwasserereignisse, edited by: Pörtgen, K. H. and Deutsch, M., Erfurter Geographische Studien, 7, 93-108, 1998.

Grebner, D.: Synoptische Zirkulationen während Extremniederschlägen in der nordalpinen Schweiz, Aktuelle Aspekte in der Hydrologie, Zürcher Geographische Schriften, 5e, 39-48, 1993.

Hächler, S.: Hochwasserereignisse im Schweizerischen Alpenraum seit dem Spätmittelalter, Raum-zeitliche Rekonstruktion und gesellschaftliche Reaktionen, Lizenziatsarbeit in Schweizergeschichte, Historisches Institut der Uni Bern, 1991.

Hilker, N., Badoux, A., and Hegg, C.: The Swiss flood and landslide damage database 1972-2007, Nat. Hazards Earth Syst. Sci., 9, 913-925, doi:10.5194/nhess-9-913-2009, 2009.

Hirschboek, K. K., Ely, L. L., and Maddox, R. A.: Hydroclimatology of meteorologic floods, Inland flood hazards: human, riparian and aquatic communities, Cambridge, 2000.

Holzhauser, H. and Zumbühl, H. J: Holocene Glacial Fluctuations, Blatt 3.8, Hydrologischer Atlas der Schweiz, Bern, Landeshydrologie und Geologie, 1999.

IPCC: Climate change and water, Intergovernmental panel on climate change, IPCC technical paper VI, 200 pp., 2008.

Jacobeit, J., Philipp, A., and Nonnenmacher, M.: Atmospheric circulation dynamics linked with prominent discharge events in Central Europe, Hydrolog. Sci. J., 51, 5, 946-965, 2006.

Jacobeit, J., Glaser, R., Luterbacher, J., and Wanner, H.: Links between flood events in central Europe since AD 1500 and largescale atmospheric circulation modes, Geophys. Res. Lett., 30, 1172-1175, 2003.

Jacobeit, J., Glaser, R., Nonnenmacher, M., and Stangl, H.: Hochwasserentwicklung in Mitteleuropa und Schwankungen der atmosphärischen Zirkulation, Geographische Rundschau, 56, 26-34, 2004.

James, C. K.: Large increase in flood magnitude in response to modest changes in climate, Nature, 361, 430-432, 1993.
Jiang, T., Zhang, Q., Blender, R., and Fraedrich, K.: Yangtze Delta floods and droughts of the last millennium: Abrupt changes and long term memory, Theor. Appl. Climatol., 82, 131-141, 2005.

Knox, J. C.: Sensitivity of modern and Holocene floods to climate change, Quaternary Sci. Rev., 19, 439-457, 2000.

Kundzewicz, Z. W., Ulbrich, U., Brücher, T., Graczyk, D., Krüger, A., Leckebusch, G. C., Menzel, L., Pinskawar, I., Radziejewski, M., and Szwed, M.: Summer Floods in Central Europe - climate change Track?, Nat. Hazards, 36, 165-189, 2005.

Koutsoyiannis, D. and Montanari, A.: Statistical analysis of hydroclimatic time series: Uncertainty and insights, Water Res. Res., 43(5), W05429, doi:10.1029/2006WR005592, 2007.

Lean, J.: Solar Irradiance Reconstruction, IGBP PAGES/World Data Center for Paleoclimatology, Data Contribution Series \# 2004-035, NOAA/NGDC Paleoclimatology Program, Boulder CO, USA, 2004

Lean, J.: Evolution of the Sun's Spectral Irradiance since the Maunder Minimum, Geophys. Res. Lett., 27, 16, 2425-2428, 2000.

Luterbacher, J., Xoplaki, E., Dietrich, D., Jones, P. D., Davies, T. D., Portis, D., Gonzalez-Rouco, J. F., von Storch, H., Gyalistras, D., Casty, C., and Wanner, H.: Extending North Atlantic Oscillation Reconstructions Back to 1500, Atmos. Sci. Lett., 2, 114-124, 2002a.

Luterbacher, J., Xoplaki, E., Dietrich, D., Rickli, R., Jacobeit, J., Beck, C., Gyalistras, D., Schmutz, C., and Wanner, H.: Reconstuction of sea level pressure fields over the Eastern North Atlantic and Europe back to 1500, Clim. Dynam., 18, 545-561, 2002 b.

Luterbacher, J., Schmutz, C., Gyalistras, D., Xoplaki, E., and Wanner, H.: Reconstruction of monthly NAO and EU indices back to AD 1675, Geophys. Res. Lett., 26, 2745-2748, 1999.

Macdonald, N., Werritty, A., Black, A. R., and McEwen, L. J.: Historical and pooled flood frequency analysis for the River Tay at Perth, Scotland, Area, 38.1, 34-46, 2006.

Macklin, M. G. and Rumsby, B. T.: Changing climate and extreme floods in the British uplands, Trans. Inst. Br. Geogr., NS 32, 168 186, 2007.

Margot, A., Sigg, R., Schädler, B., and Weingartner, R.: Beeinflussung der Fliessgewässer durch Kraftwerke und Seen, Blatt 5.3., Hydrologischer Atlas der Schweiz, Bern, Landeshydrologie und Geologie, 1991.

Mudelsee, M., Börngen, M., Tetzlaff, G., and Grünewald, U.: Extreme floods in central Europe over the past 500 years: Role of cyclone pathway "Zugstrasse Vb", J. Geophys. Res., 109, D23101,, doi:10.1029/2004DJ005034, 2004.

Mudelsee, M., Börngen, M., Tetzlaff, G., and Grünewald, W.: No upward trends in the occurrence of extreme floods in central Europe, Nature, 425, 166-169, 2003.

Naulet, R., Lang, M., Ouarda, T. B. M. J., Coeur, D., Bobée, B., Recking, A., and Moussay, D.: Flood frequency analysis on the Ardèche river using French documentary sources from the last two centuries, J. Hydrol., 313, 58-78, 2005.

Pauling, A. and Paeth, H.: On the variability of return periods of European winter precipitation extremes over the last three centuries, Clim. Past, 3, 65-76, doi:10.5194/cp-3-65-2007, 2007.

Pfister, Ch.: Klimageschichte der Schweiz 1525-1860 - Das Klima der Schweiz von 1525-1860 und seine Bedeutung in der Geschichte von Bevölkerung und Landwirtschaft, Band I, Academica helvetica, Verlag Paul Haupt, Bern, 1984. 
Pfister, Ch.: Wetternachhersage - 500 Jahre Klimavariationen und Naturkatastrophen (1496-1995), Verlag Paul Haupt, Bern, 1999.

Pfister, Ch.: Raum-zeitliche Rekonstruktion von Witterungsanomalien und Naturkatastrophen 1496-1995, Schlussbericht NFP 31, Vdf, Zürich, 1998.

Redmond, K. T., Enzel, Y., House, P. K., and Biondi, F.: Climate Variability and Flood Frequency at Decadal to Millennial Time Scales, in: Ancient Floods, Modern Hazards: Principles and Applications of Paleoflood Hydrology, edited by: House, P. K., Webb, R. H., Baker, V. R., and Levish, D. R., Water. Sci. Appl., 5, 21-54, 2002.

Röthlisberger, G.: Chronik der Unwetterschäden in der Schweiz, WSL Bericht 330, 1991.

Schaub, D., Horat, P., and Naef, F.: Die Hochwasser der Reuss im 18. und 19. Jahrhundert und ihr Einfluss auf die Hochwasserstatistik, Wasser, Energie, Luft, 3/4, 1990.

Schmocker-Fackel, P. and Naef, F.: More frequent flooding?, Changes in flood frequency in Switzerland since 1850, J. Hydrol., 381, 1-8, 2010.

Solanki, S. K., Usoskin, I. G., Kromer, B., Schüssler, M., and Meer, J.: Unusual activity of the Sun during recent decades compared to the previous 11'000 years, Nature, 431, 1084-1087, 2004.

Sturm, K., Glaser, R., Jacobeit, J., Deutsch, M., Brázdil, R., Pfister, Ch., Luterbacher, J., and Wanner, H.: Hochwasser in Mitteleuropa seit 1500 und ihre Beziehung zur atmosphärischen Zirkulation, Petermanns Geograpische Mitteilungen, 145, 2001/6, 1423, 2001.
Trouet, V., Esper, J., Graham, N. E., Baker, A., Scourse, J. D., and Frank, D. C.: Persistent Positive North Atlantic Oscillation Mode Dominated the Medieval Climate Anomaly, Science, 324, 78-80, 2009.

Vaquero, J. M.: Solar signal in the number of floods recorded for the Tagus river basin over the last millennium, Clim. Change, 66, 23-26, 2004.

VAW: Risikoanalyse Renggbach, Studie über die Überschwemmungsgefahr in Kriens, Horw und der Stadt Luzern infolge seltener Hochwasser im Renggbach, VAW Bericht, 4130, Zürich, 1995.

Vischer, D.: Die Geschichte des Hochwasserschutzes in der Schweiz - Von den Anfängen bis ins 19. Jahrhundert, Berichte des BWG, 5, Bern, 2003.

Wanner, H., Holzhauser, H., Pfister, C., and Zumbühl, H.: Interannual to century scale climate variability in the European Alps, Erdkunde, 54, 62-68, 2000.

Wanner, H., Beck, C., Brázdil, R., Casty, C., Deutsch, M., Glaser, R., Jacobeit, J., Luterbach, J., Pfister, C., Pohl, S., Sturm, K., Werner, P. C., and Xoplaki, E.: Dynamic and socioeconomic aspects of historical floods in Central Europe, Erdkunde 58, 1-16, 2004.

Weikinn, C.: Quellentexte zur Witterungsgeschichte Europas von der Zeitenwende bis zum Jahre 1850, Hydrographie Teile 1-6 (Zeitwende-1859), Akademie-Verlag, Berlin, 1958-2002. 